\title{
Editorial
}

\section{Sustainable Chemistry-A New Open Access Journal}

\author{
Matthew D. Jones
}

check for

updates

Citation: Jones, M.D. Sustainable Chemistry-A New Open Access Journal. Sustain. Chem. 2021, 2, 381. https://doi.org/10.3390/suschem 2020021

Received: 7 June 2021

Accepted: 7 June 2021

Published: 16 June 2021

Publisher's Note: MDPI stays neutral with regard to jurisdictional claims in published maps and institutional affiliations.

\section{Copyright: (C) 2021 by the author.} Licensee MDPI, Basel, Switzerland. This article is an open access article distributed under the terms and conditions of the Creative Commons Attribution (CC BY) license (https:// creativecommons.org/licenses/by/ $4.0 /)$.

\author{
Department of Chemistry, University of Bath, Claverton Down, Bath BA2 7AY, UK; mj205@bath.ac.uk
}

There are many issues facing society, such as energy/food/water security, plastic pollution, antibiotic resistance, global warming and the COVID-19 pandemic. To solve these (and other issues), scientists and engineers need to work together to tackle these imminent dangers. Chemistry can help to unlock these challenges and provide solutions for a brighter future. The field of Green (or Sustainable) Chemistry has been transformed in the last 30 years since Warner and Anastas [1] pioneered the now famous "12 Principles of Green Chemistry". Now, it is relatively common to see an E-factor [2] or a Life-CycleAssessment to support the sustainable credentials of chemical processes, and their use will only grow in coming years [3].

It is undoubtedly exciting to read and follow the major advances in the area of Green Chemistry. The journal, Sustainable Chemistry (published by MDPI), aims to be one of the go-to journals in the area, publishing cutting-edge research in the area more broadly. The open access model allows our work to reach a broad base of readers from all corners of the world. I warmly invite you to submit your latest work and, if you have any questions, do not hesitate to contact the editorial team.

\section{References}

1. Anastas, P.T.; Warner, J.C. Green Chemistry: Theory and Practice; Oxford University Press: New York, NY, USA, 1998.

2. Sheldon, R.A. The E factor: Fifteen years on. Green Chem. 2007, 9, 1273. [CrossRef]

3. Kralisch, D.; Ott, D.; Gericke, D. Rules and benefits of life cycle assessment in green chemical process and synthesis design: A tutorial review. Green Chem. 2015, 17, 123-145. [CrossRef] 